\title{
GLOBAL MENTAL HEALTH: CHALLENGES FOR A GLOBAL ETHICS
}

\section{Fernando Lolas ${ }^{1}$}

\begin{abstract}
This paper aims at presenting a perspective on a global ethics useful for conducting and evaluating research on global mental health. It includes the proposal of expanding the scope of "global" to include different aspects of cultural diversity and a plea for a "differential ethics" approach that accepts diversity and sociocultural determinants of health. The contention is advanced that ethics is a linguistic justification of moral norms based on customs, beliefs, and traditions. Besides its foundation on rational or religious beliefs, ethics should also be conceived of as a way of attaining human fulfillment of interests and expectations in the context of different forms of humanity.
\end{abstract}

Key words: global mental health, global ethics, differential ethics

\section{Salud Mental Global: retos para una ética global}

Resumen: Este texto se propone presentar una perspectiva sobre una ética global útil para conducir y evaluar investigaciones sobre salud mental global. Incluye la propuesta de expandir el significado de "global" para incluir la diversidad cultural y la demanda por una "ética diferencial" que acepte la diversidad y considere los determinantes socioculturales de la salud. Se sugiere que la ética constituye una justificación lingüística de las normas morales basadas en costumbres, creencias y tradiciones. Además de fundarse en convicciones religiosas o racionales, la ética también debe concebirse como una forma de alcanzar plenitud humana en intereses y expectativas en el contexto de diversas formas de humanidad.

Palabras clave: salud mental global, ética global, ética diferencial

\section{Saúde Mental Global: desafios para uma ética global}

Resumo: Este texto se propõe apresentar uma perspectiva sobre uma ética global útil para conduzir e avaliar pesquisas sobre saúde mental global. Inclui a proposta de expandir o significado de "global" para incluir a diversidade cultural e a demanda por uma "ética diferenciada" que aceite a diversidade e considere as determinantes socioculturais da saúde. É sugerido que a ética constitui uma justificação linguística das normas morais baseadas em costumes, crenças e tradiçóes. Além de fundamentar-se em convicçôes religiosas ou racionais, a ética também deve ser concebida como uma forma de alcançar a plenitude humana em interesses e expectativas no contexto de diversas formas de humanidade.

Palavras-chave: saúde mental global, ética global, ética diferenciada

\footnotetext{
${ }^{1}$ Professor, Psychiatric Clinic, Interdisciplinary Center for Bioethics and Institute for International Relations, University of Chile, Chile Correspondence: flolas@u.uchile.cl
} 
Globalization: the paradox of the particular becoming universal

Globalization is a paradoxical process. Under this term it is usually meant the economic expansion of international trade, the impact of big capital on human life, and the access to information and resources potentially (and theoretically) available to people all over the world. On the other hand, it also means the acritical acceptance and imposition of a certain pattern of political and economic behavior deemed successful in promoting human welfare and wellbeing. Concepts such as "democracy", "economic freedom", "political liberty", "freedom of expression" and others, generated and nurtured in specific cultural environments and under concrete historical conditions are treated as "essential universals" of the human condition, irrespective of history, custom, and belief. It could be argued that the respect for such values stems more from the military and economic power of the cultures embracing them than from their being essential aspects of human life.

The inevitable consequence is ethical imperialism. This designation is only descriptive, not pejorative or antagonistic. It does not imply complaints or refusals to discuss the issues involved. It is meant to imply that, since no human practice is devoid of valoric connotations, even the most "technical" advice, indication or information carries, besides its instrumental values, deeper layers of moral implications based on implicit (tacit, unreflected) conceptions of human nature and what is good and right. The unavoidable cultural bias remains often undiscussed in the analysis of technology transfer, innovation or research, and in practical endeavors such as healthcare and education.

In addition to the implicit acceptance of models and patterns for political and economic development and sustainability, there exists the uncontested certainty that models of intellectual proficiency and scientific value hold true irrespective of culture, language, belief and habit.

The field of mental health is full of unanalyzed propositions and definitions, including the fact that sometimes mental health is equated with the medical field of psychiatry and that no universally accepted definition of mental health or mental disorder exists $(1,2)$. Directives emanated from international agencies usually consist either in stressing the need for more Western trained specialists or experts sharing the ideology of hegemonic cultures or in "downgrading" the skills and competencies of sophisticated experts. The latter may imply delegating expert chores to less qualified personnel or generating extra skills in "other" professionals like primary care physicians, social workers, or nurses.

Both solutions collide with the discourse about providing the best available care to everyone. Scarcity of trained personnel in low and middle income countries (LMIC) may militate against providing care and solutions up to the standards of developed nations. This technical advice presents the added problem that it generates expectations on solutions not appropriate or not applicable in poor environments. In keeping with a "demonstration effect" and the discourse on human rights and public goods, the standard of care suggested, being not attainable, may constitute a source of frustration and reinforces the notion that not all people are equal. Both sides of the argument, the one proposing a high standard of professional care and the one demanding such care in all contexts, coincide with the notion that scientific progress should serve humankind and that equity might be equivalent to equality. These ideas ignore the fact that even the definition of a good "outcome" of interventions is ambiguous: it depends on expectations, culture, and socioeconomic conditions(3).

The "gaps", the divides and the tensions between the individual and the community

It is customary to formulate the disparities between LMIC and developed nations in terms of "gaps". The 10/90 gap suggests that $10 \%$ of the world population benefits from $90 \%$ spending in health research. The "know-do" gap emphasizes that knowledge is not used in efficient forms to solve problems. Knowledge accumulated in research centers is not always translated into practical solutions, widening the distance between poor and rich populations. Access to knowledge is hampered by the "digital divide" between industrialized and less industrialized nations, not to mention language barriers, moratoria and con- 
fidentiality imposed by the industrial-military complex, or communication styles influenced by cultural tradition.

Other gaps are described. The expression "treatment gap" indicates the unavailability of therapeutic resources essential for managing mental disorders in certain world regions. This is one aspect of the "resource gap", the scarcity of personnel and facilities for dealing with mental pathologies, coupled with a relatively low attention to financial needs of the mental health sector in national budgets(4).

"Boundary effects" are observed: while data and information have restrictions for wide diffusion, moral consequences of knowledge impact rapidly. Frontier research that opens possibilities for understanding and treating disease is not possible in underdeveloped scientific communities, but its results open hopes and expectations in poor populations or lead to paradoxical restrictions on research practices. Such is the case of research on cloning, stem cell research or advanced neuroscience. Latin American and African countries, for example, reproduce regulations and legislation prohibiting some forms of research intended to protect subjects but their technical infrastructure does not permit them. Those gaps, divides, and comparisons are based on an implicitly defined standard: the one developed in countries of the North and published in English. Underrepresentation of other languages in the academic corpus of current psychiatry is evident(5).

The tension between the individual and the group has an impact on research practices and on the translation from laboratory to clinical work. Most of the underlying assumptions of Western science relate to individual human rights and some streams of thought contrast this position with the common good of populations. Theoretical reflection is needed to harmonize the welfare of the individual with the wellbeing of populations or groups. The argument needs to be formulated not only contrasting individuals and national communities. In an age of globalization, individuals are embedded in successive layers of group belonging, from the nearest to the farthest. 21 st century citizens do belong, simultaneously, to their local reference groups (family, national communities) and to the population of the world at large. This constellation of human relations is unprecedented in history. It is partly responsible for the feeling that all humans belong into the same space and are entitled to the same rights, irrespective of their geographical situation. While being a true and appealing assertion, it does not match the real-world circumstances of people in different world regions. Under the assumption that the biological body is the same, cultural differences are disregarded, ignoring the fact that even the most biological or empirical information is shaped by culture. It affects the way in which data are collected, organized, and communicated. Since tools shape thought, instruments determine what is empirically accessible and what is not. And belief systems are pervasive components of the scientific framework.

\section{The meaning of global in global mental health}

Global mental health is not an unambiguous designation. It includes the notion of geographical extension, beyond national boundaries, with a possible implication for all peoples in the world. It does not have the connotation of international health, which stresses the national differences and was used in the past as a label for neocolonialist postures.

An interesting use of the term "global" is to employ it to cover all aspects of human life. This usage is warranted insofar as the interests of humans may vary greatly between and within national borders and populations. For some peoples, religious belief is more important than for others. Autonomy is appreciated more in some ethnic or national societies than in others. The conditions for normality may stretch from very basic notions to a highly sophisticated lifestyle. A hungry and deprived population is certainly different from a wealthy one. Thus, the "globality" of interests, conditions for happiness, and normality may be quite complex to ascertain if one abandons the utopic thought that the human organism is the same irrespective of contexts and history. Global also means integral, biopsychosocial, or holistic, with the added connotation of cultural diversity.

This meaning permits a comparative and culturally sensitive consideration and a better analysis of 
ethical dilemmas, allowing what Sass aptly terms a "differential ethics" approach(6). Imposed "universal" notions of wellbeing fail because they do not consider this differential embodiment and embeddedness of human beings. "Health" in some quarters may leave aside aspects that in others are deemed essential. "Global health" as "integral health" captures both the universality of the claim to humanness and the particular value constellation of different individuals. It also helps to establish global as an attribute of humanity across cultures and historical periods(7).

The historical expectation of psychiatry has been to translate clinical labels into natural entities in order to become a medical specialty relating etiology to anatomy or physiology. The reliance upon course, processes or developments instead of a real bodily lesion or phenomenon makes almost impossible to chart similarities and compare phenomena in different contexts. The connotation of global as integral but variable, rejecting homogeneity, indicates that mental health (encompassing different and relevant aspects of life for a given human being) is, and should be, quite diverse depending upon context, culture, and tradition. The "Umwelt" of a member of an African tribe is different from the environment of a suburban dweller in New York. And global (in the sense of embracing all aspects of embeddedness) has a different meaning for these two persons. According to Kleinman(8), academic psychiatry, with its current emphasis on neuroscientific reductionism and dependence from pharmaceutical industry, should reorient itself to a wider social horizon in order not to become irrelevant. This is all the more evident considering the small numbers of specialists in LMICs and their concentration in urban areas, not to mention language barriers for research and experiences published in languages other than English. A paradigm change, as advocated by some(9), does not solve the main issue, which seems to be a more intense involvement of other professionals and lay people in the construction of mental health, as a pursuit wider than the treatment of mental disorders.

\section{Moral and ethics}

Moral is the unreflected existence of norms and rules of conduct based on tradition, custom and belief. Ethics, on the other hand, is the linguistic and rational elaboration of what is good or bad. It aims at justifying certain forms of behavior based on a theory of human nature. Moral presents people with unconscious options; ethics is a discursive action that justifies acts on the basis of a general formulation or statement, philosophical or religious. The essential point is that they not only propose but justify (or impose) behavioral options.

The real ethical challenge is to develop constructs that are justifiable and respect individual features while at the same time preserve the reference groups to which a given individual belongs. This is the essence of a just set of institutions, according to Paul Ricoeur(10). Since any given individual belongs simultaneously to different groups or populations, there are "layers of embeddedness" (family, groups of affinity, ethnic groups, nations, humanity as a whole). Most of ethics theories deal with social face to face interactions; when these are missing or impossible the challenge is to develop a "moral imagination" permitting empathy, solidarity and reciprocity with human beings remote in space or time who will never be heard or seen.

Ethics in times of globalization does not imply imposing a worldview or Weltanschauung on people but on considering (differentially) the integrity of human life diversely configured in different individuals and groups as they identify with or claim allegiance to (culture, ethnicity, language, among others). People inhabit diverse environments, even assuming a common speciesspecific genetic background; the "epigenetic construction of the human self" (and attributes like health and wellbeing) is infinite. Uniformity and sameness do not hold true even for the biological substrate of humanness. Global mental health, ethically and technically considered, must consider a "differential ethics approach" in the above defined sense.

\section{Glocalization and ethics}

All ethics is local. Humans inhabit different valoric universes and semantic spaces. The motto of WHO rightly indicates "think globally, act locally". This emphasizes that aspirations may and 
should be common to all human beings but their specification and realization are diverse. "Global" ideas should be implemented as" local" actions.

Reliance on "human rights" fails because it is not enough to accept rights without considering how they are ascertained or understood, or how claims to entitlement can be honored. The two strands of justice, one individualistic and the other collective (based on "common good" considerations) are not antagonistic but complementary. Considering how often and how variously human rights are violated, it might be more practical to demand a "universal declaration of human duties". Such a proclamation would by necessity incorporate the duty to solidarity and reciprocity in human relations, irrespective of geography, culture, and socioeconomic status. Ours is a world of "moral strangers" and "epistemic strangers". Humans do not believe in the same things and understand them differently, even if similar words are used. Nuances are also crucial. Consider the difference between "plaisir" and "bonheur" in the French language or between Macht and Gewalt in German, pouvoir and puisance in French, poder and potestad in Spanish. Even more compelling, moral words are different in different languages: for instance, "fairness" translated as Gerechtigkeit in German, or justicia in Spanish addresses in each case a different semantic space).

Challenges for global ethics in global mental health

Mental health is a "neurocultural construction" based on nature and nurture intertwined in irrevocable ways. Neuroscience and the social sciences should arrive at the same final end (health or wellbeing) while differing in the means to create, promote or preserve it. The long struggle between a "mindless physiology" and a "brainless psychology" indicates the need to overcome partial reductionisms, disparate languages and contradictory practical implications. The complementarity should overcome juxtaposition of languages and techniques. It must accept that full human potential can be achieved under diverse conditions. An integrative language recognizing diversity in the context of universal humanness is necessary. The task ahead is to teach individuals that others belong to other groups and that distinctions sometimes entail differences and sometimes are arbitrary.

Economic globalization created the divide between the "haves" and the "have-nots". One of its consequences has been collapse or disruption of the social fabric in some regions of the world. The fracture of the social structures is also a disruption of the valoric world. Unemployment, terrorism, violence, and insecurity are some of its consequences. The "visible losers" in the globalization game show that "free trade" is sometimes "managed trade", leading to inequalities, social turmoil, and immoral behavior.

Since the "right to health" is never a right to health alone (sometimes the technical jargon calls for "intersectorial approaches"), social determinants of health must be considered in mental health policies. Conceptualization of impairments, disabilities and handicaps as "mental health problems" or "mental disorders" is a shifting target. Catalogs of illnesses and diseases vary with each new edition of standard manuals or training courses. The influence of industry and economy in shaping the borders of normalcy and disease are a powerful inducement to create pathologies for which "solutions" are provided by industry, even if they are not felt as "problems" by the affected populations.

In addition to the normative dimension associated with the word "ethics", it is undoubtedly a means for personal growth and what Cooley(11) calls "flourishing", the attainment of a full human perfect life. Virtue was understood in classical writings as personal human perfection. Although an individual enterprise, society and institutions should provide the foundations for this achievement. In technical terms, preconditions for a good quality of life (and personal fulfillment) depend on organized group efforts. This is the traditional "ethos" of public health. Individuals may or may not attain virtues (perfections), but opportunities should be provided. A just society is one in which institutions are structured in a way that harmonizes individual rights and duties with the common good. Mental health as public or common good(12) involves a right to diversity: it should be universally attainable, uniformly possessed and non-rivalrous with other goods. These attributes 
are not observed in current landscapes across the world, partly because living conditions are so diverse and inequity or inequalities prevail. An ethical challenge involves thus a reasoned priority setting on the part of administrators, politicians and policymakers(13). Prioritizing what makes humans human and permit enjoyment of civilizatory goods is essentially an ethical challenge, not simply a technical one. Modern ethical theorization calls for dialogue and deliberation. This should be considered when establishing goals or justifying means. The "new architecture for global mental health" (14) demands ethics in this sense. Technical foundation and moral justification should go hand in hand when formulating policies. By definition, scarcity dictates the need for priority setting when striving at the achievement of common goods. But a rational and reasonable standard is not a matter of imposing a worldview but of accepting diversity and belief.

\section{Referencias}

1. Summerfield, D. Afterword: Against "global mental health". Transcultural Psychiatry 2012; 49: 519-530.

2. Galderisi S, Heinz A, Kastrup M, Beezhold J, Sartorius N. Toward a new definition of mental health. World Psychiatry 2015; 14(2): 231-233.

3. Thornicroft G, Slade M. New trends in assessing the outcomes of mental health interventions. World Psychiatry 2014; 13(2): 118-124.

4. Patel V. Global mental health: from science to action. Harvard Review of Psychiatry 2012; 20(1): 6-12. DOI: 10.3109/10673229.2012.649108

5. F. Editorial: Language, psychiatry and globalization: the case for Spanish-speaking psychiatry. Asia Pacific Psychiatry 2010; 2: 4-6.

6. Sass HM. Differentialethik: Anwendungen in Medizin, Wirtschaft und Politik. Berlin: Lit Verlag; 2006.

7. Lolas F. Differential ethics in global mental health. JAHR. European Journal of Bioethics 2015; 6(2): 247-254.

8. Kleinman A. Rebalancing academic psychiatry: why it needs to happen-and soon. British Journal of Psychiatry 2012: 201: 421-422.

9. Bracken P, Thomas O, Timimi S, Asen E, et al. Psychiatry beyond the current paradigm. British Journal of Psychiatry 2012; 201: 430-434.

10. Ricoeur P. Soi-méme comme un autre. Paris: Editions du Seuil; 1990.

11. Cooley DR. Death's values and obligations: a pragmatic framework. Dordrecht: Springer; 2015.

12. Lolas F. Salud mental global como bien público: sugerencias para la reflexión ética. Revista de Neuropsiquiatría (Lima) 2013; 76(3): 131-136.

13. Lolas F, Martin D, Quezada A. Prioridades en salud y salud intercultural. Santiago de Chile: CIEB Universidad de Chile; 2007.

14. Kirmayer LJ, Pedersen, D. Toward a new architecture for global mental health. Transcultural Psychiatry 2014; 51(6): 759-776.

Received: February 8, 2016

Accepted: February 15, 2016 